\title{
Lacustrine wetland in an agricultural catchment: nitrogen removal and related biogeochemical processes
}

\author{
R. Balestrini, C. Arese, and C. Delconte \\ Water Research Institute (IRSA-CNR), via della Mornera 25, Brugherio 20047, Milano, Italy \\ Received: 18 September 2007 - Published in Hydrol. Earth Syst. Sci. Discuss.: 28 September 2007 \\ Revised: 18 January 2008 - Accepted: 10 February 2008 - Published: 10 March 2008
}

\begin{abstract}
The role of specific catchment areas, such as the soil-river or lake interfaces, in removing or buffering the flux of $\mathrm{N}$ from terrestrial to aquatic ecosystems is globally recognized but the extreme variability of microbiological and hydrological processes make it difficult to predict the extent to which different wetlands function as buffer systems. In this paper we evaluate the degree to which biogeochemical processes in a lacustrine wetland are responsible for the nitrate removal from ground waters feeding Candia Lake (Northern Italy). A transect of 18 piezometers was installed perpendicular to the shoreline, in a sub-unit formed by $80 \mathrm{~m}$ of poplar plantation, close to a crop field and $30 \mathrm{~m}$ of reed swamp. The chemical analysis revealed a drastic $\mathrm{NO}_{3}^{-}-\mathrm{N}$ ground water depletion from the crop field to the lake, with concentrations decreasing from $15-18 \mathrm{mg} \mathrm{N} / \mathrm{l}$ to the detection limit within the reeds. Patterns of $\mathrm{Cl}^{-}, \mathrm{SO}_{4}^{2-}, \mathrm{O}_{2}, \mathrm{NO}_{2}^{-}-\mathrm{N}, \mathrm{HCO}_{3}^{-}$and DOC suggest that the metabolic activity of bacterial communities, based on the differential use of electron donors and acceptors in redox reactions is the key function of this system. The significant inverse relationship found between $\mathrm{NO}_{3}^{-}-\mathrm{N}$ and $\mathrm{HCO}_{3}^{-}$is a valuable indicator of the denitrification activity. The pluviometric regime, the temperature, the organic carbon availability and the hydrogeomorphic properties are the main environmental factors affecting the $\mathrm{N}$ transformations in the studied lacustrine ecosystem.
\end{abstract}

\section{Introduction}

Knowledge of the processes controlling the extent and dynamics of nutrient fluxes from diffuse sources in heterogeneous catchments is crucial in predicting and controlling

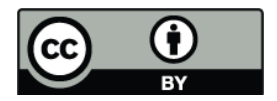

Correspondence to: R. Balestrini (balestrini@irsa.cnr.it) the effect of human activities on the environment. Unlike point source pollution, diffuse pollution cannot easily be controlled, a reduction can only be achieved by appropriate land management techniques. It is well known that modern agricultural practices significantly contribute to catchment nitrogen losses. In Italy for example, agriculture accounts for $68 \%$ of nitrogen $(\mathrm{N})$ input to the Po river catchment and this percentage increases to $83 \%$ if we consider the $\mathrm{N}$ input to groundwater (Autorità di Bacino del fiume Po, 2003). In the Po Valley, nitrate $\left(\mathrm{NO}_{3}^{-}\right)$contamination of ground waters considerably constrains the readily available amount of drinking water.

Over the last few decades, much interest has been focused on specific catchment areas such as riparian zones which are able to reduce or buffer the flux of $\mathrm{N}$ from terrestrial to aquatic ecosystems (Peterjohn and Correll, 1984; Haycock et al., 1993; Sabater et al., 2003). The significant role of wetland can be seen in the European Water Framework Directive's (EU, 2000/60), recent integrated approach to river basin management in Europe. In this framework, riparian areas are considered as a significant element of the hydrological network in which protection and restoration are required to achieve "good water status" for surface and ground waters (Wetlands Horizontal Guidance, 2003).

Riparian areas may attenuate nitrogen inputs to aquatic ecosystems through plant uptake, microbial denitrification, soil storage and dilution (Hill, 1990; O'Neill and Gordon, 1994; Haycock and Pinay, 1993; Groffman et al., 1996; Devito et al., 2000). More attention has focused on denitrification as this process can lead to a real removal of $\mathrm{N}$ by the transformation of dissolved $\mathrm{N}$ into gaseous forms, till favourable conditions for denitrifying bacteria persist. The relative importance of these processes seems to be strictly linked to the hydrological properties of soil-water interfaces (Mitsch and Gosselink, 2000; Pinay et al., 2000; Burt et al., 2002).

Published by Copernicus Publications on behalf of the European Geosciences Union. 
Table 1. Median concentration of major physical and chemical variables in samples collected between December 2003 and July 2004.

\begin{tabular}{lrrrrrrrrrrr}
\hline & $\mathrm{T}$ & $\mathrm{pH}$ & $\mathrm{HCO}_{3}^{-}$ & $\mathrm{NH}_{4}^{+}-\mathrm{N}$ & $\mathrm{NO}_{3}^{-}-\mathrm{N}$ & $\mathrm{NO}_{2}^{-}-\mathrm{N}$ & $\mathrm{ON}$ & $\mathrm{SO}_{4}^{2-}$ & $\mathrm{Cl}^{-}$ & $\mathrm{O}_{2}$ & $\mathrm{DOC}$ \\
\hline & ${ }^{\circ} \mathrm{C}$ & & $\mathrm{meq}^{-1}$ & $\mathrm{mg} \mathrm{l}^{-1}$ & $\mathrm{mg} \mathrm{l}^{-1}$ & $\mathrm{mg} \mathrm{l}^{-1}$ & $\mathrm{mg} \mathrm{l}^{-1}$ & $\mathrm{mg} \mathrm{l}^{-1}$ & $\mathrm{mg} \mathrm{l}^{-1}$ & $\mathrm{mg} \mathrm{l}^{-1}$ & $\mathrm{mg} \mathrm{l}^{-1}$ \\
$\mathrm{P} 1$ & 11.7 & 6.17 & 0.60 & 0.018 & 14.76 & & 0.69 & 16.9 & 12.6 & 2.35 & 2.04 \\
$\mathrm{P} 2$ & 11.7 & 6.61 & 1.97 & 0.015 & 10.29 & 0.13 & 0.31 & 20.8 & 14.0 & 1.90 & 2.11 \\
$\mathrm{P} 3$ & 10.5 & 7.00 & 3.20 & 0.012 & 13.06 & 0.13 & 0.81 & 36.2 & 16.5 & 1.68 & 2.93 \\
$\mathrm{P} 4$ & 10.9 & 6.90 & 3.72 & 0.012 & 8.06 & 0.11 & 0.35 & 45.4 & 17.8 & 1.31 & 3.89 \\
$\mathrm{P} 5$ & 11.3 & 7.02 & 5.03 & 0.012 & 4.85 & 0.15 & 0.51 & 56.7 & 17.5 & 0.85 & 4.35 \\
$\mathrm{P} 6$ & 10.8 & 7.00 & 4.49 & 0.010 & 5.76 & 0.16 & 0.46 & 52.5 & 16.2 & 0.62 & 4.51 \\
$\mathrm{P} 7$ & 11.7 & 7.15 & 5.04 & 0.027 & 3.69 & 0.10 & 0.35 & 51.5 & 15.2 & 1.39 & 3.82 \\
$\mathrm{P} 8$ & 14.2 & 7.41 & 7.00 & 0.015 & 0.08 & & 0.30 & 92.1 & 14.9 & 2.39 & 4.34 \\
$\mathrm{P} 9 \mathrm{~s}$ & 13.5 & 6.86 & 4.16 & 0.063 & 0.33 & & 0.50 & 77.2 & 13.7 & 1.55 & 5.03 \\
$\mathrm{P} 9 \mathrm{~d}$ & 13.9 & 7.17 & 7.71 & 0.031 & 0.00 & & 0.24 & 34.0 & 9.5 & 1.17 & 3.89 \\
$\mathrm{R} 1 \mathrm{~s}$ & 12.2 & 6.22 & 2.37 & 0.356 & 0.03 & & 2.47 & 197.7 & 12.6 & 0.69 & 15.01 \\
$\mathrm{R} 1 \mathrm{~m}$ & 11.6 & 6.89 & 9.24 & 0.047 & 0.05 & & 1.27 & 31.3 & 4.4 & 2.82 & 5.90 \\
$\mathrm{R} 1 \mathrm{~d}$ & 12.2 & 6.85 & 10.19 & 0.029 & 0.00 & & 0.71 & 0.7 & 2.8 & 1.55 & 5.10 \\
$\mathrm{R} 2 \mathrm{~s}$ & 12.0 & 6.48 & 2.71 & 0.138 & 0.05 & & 1.07 & 276.4 & 10.5 & 0.50 & 8.29 \\
$\mathrm{R} 2 \mathrm{~m}$ & 12.9 & 6.90 & 8.75 & 0.041 & 0.05 & & 0.86 & 6.7 & 4.6 & 3.25 & 6.63 \\
$\mathrm{R} 2 \mathrm{~d}$ & 11.4 & 6.93 & 9.92 & 0.016 & 0.00 & & 0.51 & 0.7 & 1.5 & 1.16 & 6.22 \\
$\mathrm{R} 3 \mathrm{~s}$ & 11.8 & 6.60 & 4.41 & 0.532 & 0.05 & & 0.96 & 84.2 & 9.6 & 0.78 & 7.90 \\
$\mathrm{R} 3 \mathrm{~d}$ & 11.5 & 6.75 & 7.68 & 0.198 & 0.05 & & 1.08 & 0.7 & 8.3 & 0.91 & 6.46 \\
lake & 17.0 & 7.95 & 1.08 & 0.088 & 0.18 & & 0.64 & 6.2 & 4.8 & 10.60 & 7.04 \\
\hline
\end{tabular}

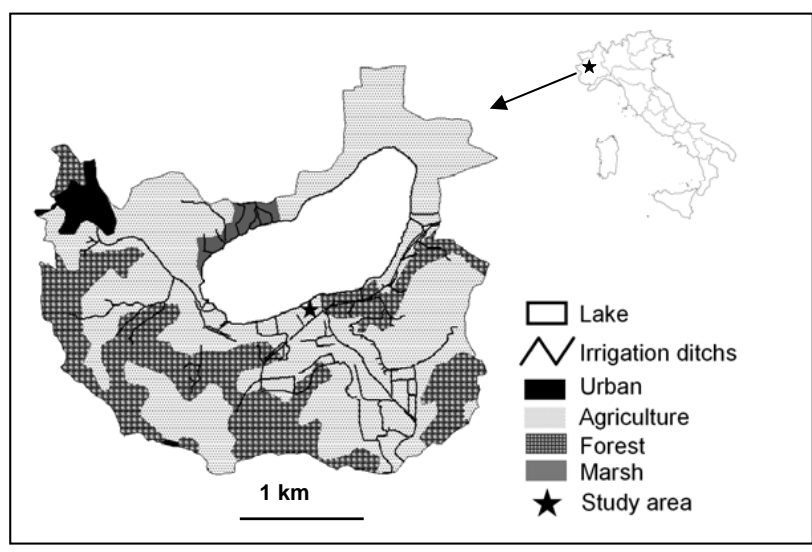

Fig. 1. Map location of Candia Lake catchment.

Despite the increasing number of papers over recent years on the role of riparian areas in $\mathrm{N}$ removal, the extreme variability of microbiological and hydrological processes make it difficult to predict the extent to which different wetlands function as buffer systems. In some areas less than $5 \mathrm{~m}$ is enough to remove all the $\mathrm{NO}_{3}^{-}$entering the riparian areas (Balestrini et al., 2007; Blicher-Mathiesen and Hoffman, 1999), while in others, little or no N removal is observed (Devito et al., 1989). Little research has been conducted in large upland aquifers receiving high $\mathrm{N}$ inputs and little information is available on the variability of the depth of denitrifying activity in riparian zones (Hill et al. 2000). In addition, in
Italy, with the scarcity of ongoing studies on natural wetlands (Balestrini et al., 2004; Borin et al., 2004), there is a need to observe typologies characteristic of the national territory.

The general aim of the present paper is to evaluate the $\mathrm{N}$ buffering capacities of a riparian area adjoining a small lake (Lake Candia) which receives a large nutrient input from agricultural land. We examined spatial and temporal variation in water chemistry and hydrology to identify the main mechanisms (biological, physical, chemical) leading to ground water $\mathrm{NO}_{3}^{-}$depletion at soil-lake interfaces. Patterns of nitrate, dissolved oxygen, dissolved organic carbon, alkalinity and sulphate concentrations were used to delineate redox conditions and define the occurrence and location of denitrification zones. The effect of some environmental factors, such as organic carbon availability, temperature and hydromorphology, on the $\mathrm{N}$ dynamic was investigated.

\section{Methods}

\subsection{Study area}

Lake Candia $\left(45^{\circ} 19^{\prime} 25^{\prime} \mathrm{N}, 7^{\circ} 54^{\prime} 43^{\prime \prime} \mathrm{E}\right)$ is a small $\left(1.49 \mathrm{~km}^{2}\right)$, inter-morainic shallow lake, located in the region of Piedmont in North-West Italy (Fig. 1). The shoreline is almost entirely occupied by a belt of emergent macrophytes in which Phragmites australis dominates. The annual floating leaved water chestnut (Trapa natans) covers about 20 ha of the littoral zone (Galanti and Romo, 1997). Lake Candia does not have any inflows but is mainly fed from 
Table 2. Mean concentration of major chemical variables in samples collected between March and November 2003.

\begin{tabular}{lrrrrrrrr}
\hline & $\mathrm{pH}$ & $\mathrm{HCO}_{3}^{-}$ & $\mathrm{NH}_{4}^{+}-\mathrm{N}$ & $\mathrm{NO}_{3}^{-}-\mathrm{N}$ & $\mathrm{ON}$ & $\mathrm{SO}_{4}^{2-}$ & $\mathrm{Cl}^{-}$ & $\mathrm{DOC}$ \\
\hline & & $\mathrm{meq} \mathrm{1}^{-1}$ & $\mathrm{mg} \mathrm{l}^{-1}$ & $\mathrm{mg} \mathrm{l}^{-1}$ & $\mathrm{mg} \mathrm{l}^{-1}$ & $\mathrm{mg} \mathrm{l}^{-1}$ & $\mathrm{mg} \mathrm{l}^{-1}$ & $\mathrm{mg} \mathrm{l}^{-1}$ \\
P2 & 7.07 & & & 0.56 & & 24.5 & 10.4 & \\
P3 & 7.32 & 4.86 & 0.029 & 2.67 & & 33.3 & 13.8 & 2.21 \\
P4 & 7.34 & 3.45 & 0.065 & 0.34 & 1.17 & 27.2 & 11.6 & 3.38 \\
P5 & 7.42 & 4.70 & 0.201 & 0.04 & 0.77 & 26.8 & 13.0 & 6.39 \\
P6 & 7.62 & 4.38 & 0.100 & 0.10 & 1.77 & 26.3 & 12.6 & 4.95 \\
P8 & 7.52 & 4.79 & 0.145 & 0.06 & 1.34 & 32.3 & 11.3 & 6.10 \\
P9s & 7.38 & 5.26 & 0.224 & 0.06 & 2.97 & 5.7 & 9.7 & 7.65 \\
R1s & 6.77 & 3.74 & 1.212 & 0.02 & 3.56 & 174.2 & 11.2 & 30.9 \\
lake & 8.07 & 1.11 & 0.217 & 0.17 & 0.95 & 4.8 & 4.5 & 6.70 \\
\hline
\end{tabular}

groundwater and rainfall. An unconfined aquifer intercepts the lake (at $226 \mathrm{~m}$ a.s.l.) from the higher elevation of the moraine (330 m a.s.l.) on the West towards the North East. A second deeper aquifer occasionally feeds the lake. The climate of the area has been described as humid-temperate and the annual average temperature and precipitation during the 16-year period (1986-2002) was $11.1^{\circ} \mathrm{C}$ and $912 \mathrm{~mm}$, respectively. About $51.1 \%$ of the Lake Candia basin is occupied by agricultural areas, $45.5 \%$ by forests and grassland and only $3.4 \%$ by urban areas (Ciampittiello et al., 2005). It receives a large input of nutrients and its ecological status is currently classified as "poor" (DECRETO LEGISLATIVO N. 152/1999).

Field activities were conducted on the north-western shore of the lake in a sub-unit formed by $80 \mathrm{~m}$ of poplar (Populus nigra L.) plantation, in the upper part close to a crop field and $30 \mathrm{~m}$ of reed swamp mainly formed by Phragmites australis.

Farmers declared that the synthetic fertilizers regularly applied to the crop field consisted of NPK compound and ammonium nitrate for a total amount of $200 \mathrm{~kg} \mathrm{~N} \mathrm{ha}^{-1}$.

\subsection{Sampling and analysis}

A transect of piezometers was installed perpendicular to the shoreline, extending from the crop field to the lake. A total of 18 piezometers were positioned at a 5 to $15 \mathrm{~m}$ distance from one another and at a depth ranging from 1.5 to $3 \mathrm{~m}$. In the reed swamp and in the transition zone between the two sub-units the piezometers positioned at the same distance were sited in groups of two or three, at different depths: 54$80 \mathrm{~cm}$, surface (s), $143-150 \mathrm{~cm}$, middle (m), and 196-219 cm deep (d) (Fig. 2). The piezometers consisted of PE pipe $(4 \mathrm{~cm}$ id) with $10 \mathrm{~cm}$ slotted ends installed in holes drilled by hand auger. The water table elevation was measured at least once a month, from March 2003 to July 2004 using a suitable sounding probe. Ground water samples were collected with the same frequency of hydrological measurements, simultaneously in the poplar grove and in the reed swamp after at least one volume of the piezometer content had been

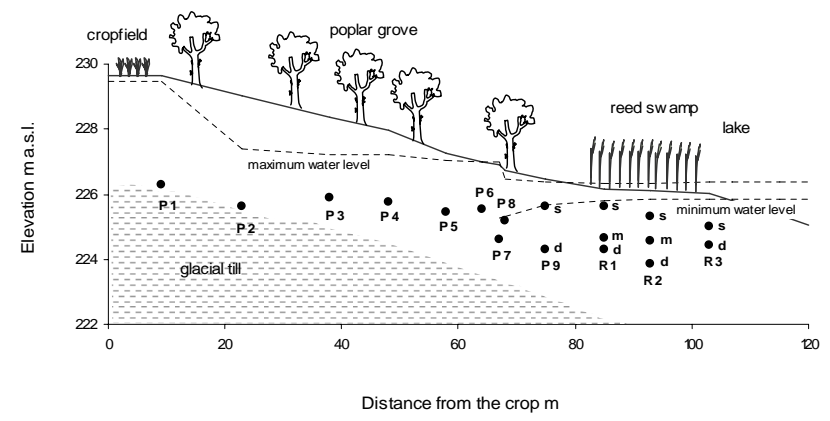

Fig. 2. Vertical cross section of the experimental field. The maximum and minimum recorded water levels are shown. Codes represent piezometer nest locations. $\bullet=$ indicate position of the piezometers screen.

removed. Lake samples were collected close to the shoreline at a depth of $20-30 \mathrm{~cm}$ at the same time as the ground water samples. Water temperature and dissolved oxygen (O2) concentration were measured in the field, during the sample collection, from May to July 2004. The scarce rainfall during spring and summer 2003 notably constrained the water availability in the soil and it was not possible to collect water in a number of the piezometers. In addition, the complete installation of piezometers in the reed swamp ended in November 2003. For these reasons the chemical data of March-November 2003 (10 samplings) is shown separately (Table 2). For a better analysis of the spatial variations we compared only the results available for all the piezometers of the studied transect corresponding to 11 sampling sessions from December 2003 to July 2004.

Soil profiles were obtained from cores collected mainly during piezometer installations. Soil samples were analyzed for organic carbon content using the WalkleyBlack method (Gaudette et al., 1974). Hydraulic conductivity was measured in the poplar sub-unit by pumping tests and calculated using the Bower and Rice equation (Bouwer and Jackson, 1976). 


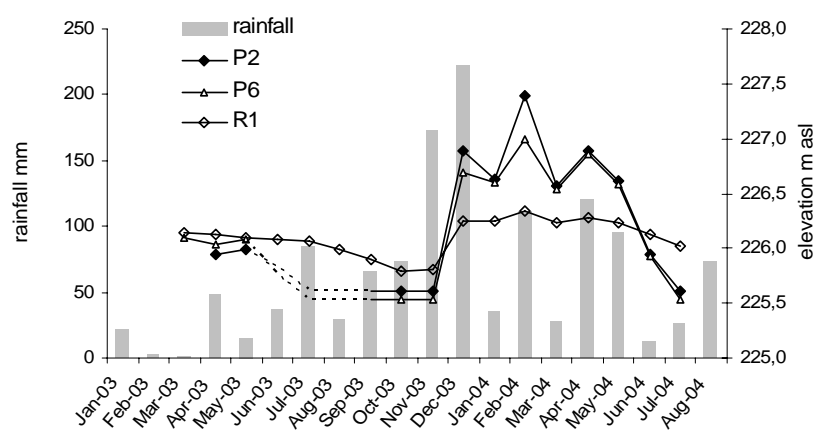

Fig. 3. Monthly variation of the water table in selected piezometers and amount of monthly rainfall.

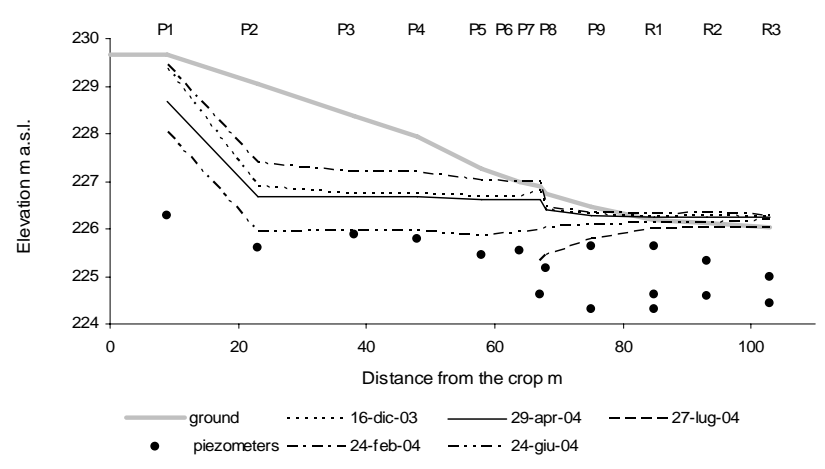

Fig. 4. Fluctuations of water table profile, averaged by row, during the study period. Codes above represent piezometer nest locations. $\bullet=$ indicate position of the piezometers screen.

Precipitation data at the meteorological station located at $2 \mathrm{~km}$ away from the experimental area were used.

The analysis was performed on filtered samples $(0.45 \mu \mathrm{m})$, except for measurements of $\mathrm{pH}$, electrical conductivity and total nitrogen $(\mathrm{TN})$, for which unfiltered samples were used. The alkalinity was measured by two-endpoint potentiometric titration with $\mathrm{HCl}$. $\mathrm{N}^{-\mathrm{NH}_{4}}$ analyzed by molecular absorption spectrometry (Perkin Elmer UV-VISLambda2) using the indophenol-blue method. $\mathrm{NO}_{3}-\mathrm{N}, \mathrm{SO}_{4}$ and $\mathrm{Cl}$ were determined by ion chromatography using a Dionex 2000i equipped with AS4A column. TN was measured using molecular absorption spectrometry, following persulphate digestion in an autoclave at $120^{\circ} \mathrm{C}$. The organic nitrogen $(\mathrm{ON})$ was estimated by comparing the difference between $\mathrm{TN}$ and inorganic $\mathrm{N}\left(\mathrm{NH}_{4}^{+}-\mathrm{N}+\mathrm{NO}_{3}^{-}-\mathrm{N}+\mathrm{NO}_{2}^{-}-\mathrm{N}\right)$. Dissolved organic carbon (DOC) was assayed by high temperature catalytic oxidation using a Shimadzu TOC-5000 A analyzer.

The quality of chemical analysis was checked by including method blanks, repeated measurements of internal and certified reference samples and by regular inter-laboratory tests and international intercomparisons (Mosello et al., 2002). The repeatabilities, based on repeated measurements of in- ternal quality controls at different concentrations, were $3 \%$ for $\mathrm{NH}_{4}^{+}-\mathrm{N}, 2 \% \mathrm{NO}_{3}^{-}-\mathrm{N}, 4 \%$ for $\mathrm{TN}, 3 \%$ for $\mathrm{SO}_{4}^{2-}, 6 \%$ for $\mathrm{Cl}^{-}$. Detection limits were $5 \mu \mathrm{gl}^{-1}$ for $\mathrm{NH}_{4}^{+}-\mathrm{N}, 0.02 \mathrm{mg} \mathrm{l}^{-1}$ for $\mathrm{NO}_{3}^{-}-\mathrm{N}$, and $\mathrm{Cl}^{-}, 0.05 \mathrm{mgl}^{-1}$ for $\mathrm{SO}_{4}^{2-}$ and $0.1 \mathrm{mgl}^{-1}$ for $\mathrm{TN}$.

\section{Results}

\subsection{Soil features}

In the soil profile, the silt layers of lacustrine origin predominate, alternated with sand and deep gravel-sandy layers. In every profile we observed redoximorphic features as grey in colour with red spots and deep grey layers. Organic matter of a very dark colour was often detected within the hydric layers. In the upper part of the transect, the soils were classified as Typic Udorthens, while those close to the lake were Aquic Udorthens. The organic carbon abundance was measured in three soil cores collected at P3, P6 and P8. Within the first $30-40 \mathrm{~cm}$ the percentages ranged between 1.8 to 2.5 ; up to $70-80 \mathrm{~cm}$ in depth the values tended to decrease to 0.4 0.8 . At a greater depth (to $150-170 \mathrm{~cm}$ ) the levels increased to $7 \%$. The hydraulic conductivity values gradually diminished from $380 \mathrm{~cm} \mathrm{~d}^{-1}$ in the upper part of the transect, to $2 \mathrm{~cm} \mathrm{~d}^{-1}$ at the end of the poplar plantation. The measured values fall into the range reported for fine sands rich in silt (Fetter, 2001).

\subsection{Hydrology}

A relevant seasonal cycle of the water table fluctuations is evident from the measurements conducted from March 2003 to July 2004. 2003 was an atypical year characterized by a very dry spring and summer, minimum water table levels were measured from the March-November period (Fig. 3). Intense precipitation events occurred at the end of November and beginning of December and consequently the water table abruptly increased in all the piezometers, particularly in those located on the hill slope (Figs. 3 and 4). The maximum values, occurred during winter 2004 , followed by minimum levels in summer 2004 when many piezometers were empty. The breadth of the cycle is greater upslope and diminishes towards the lake (Fig. 4). At P1 the variations were at least $3 \mathrm{~m}$; they reduced to $1.8-1.3 \mathrm{~m}$ within the poplar plantation, from $\mathrm{P} 2 \mathrm{~m}$ to $\mathrm{P} 6$, and they further declined to $0.7-0.5 \mathrm{~m}$ in the reed swamp. The large range measured on the hill slope suggests a pattern of winter recharge controlled by conditions occurring upslope. In contrast, the more constrained response observed in the rest of the transect, particularly near the lake, suggests that both the hill slope and the lake exert control over the riparian water table. In mid-summer (27 July) when the slope discharge fell to under measurable levels, probably because of high evaporation losses and lack of rainfall, 

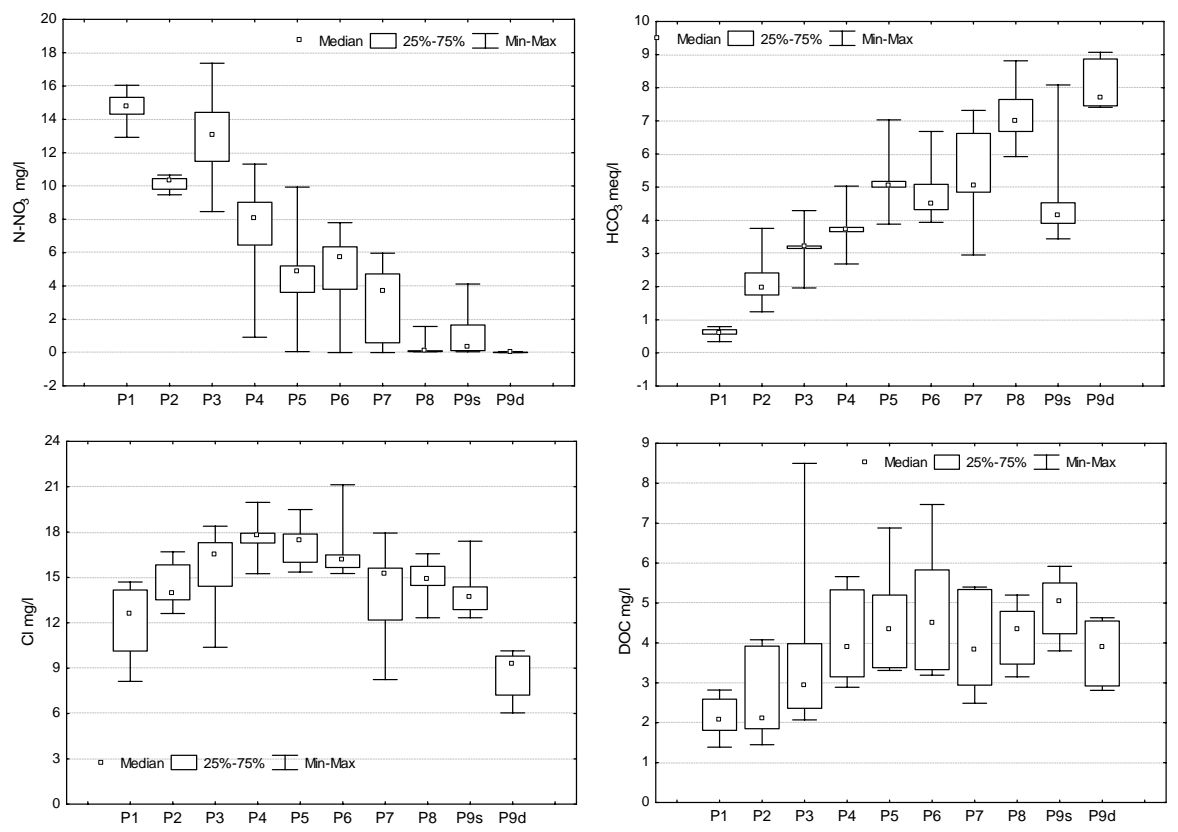

Fig. 5. Boxplot showing the distribution of $\mathrm{NO}_{3}^{-}-\mathrm{N}, \mathrm{HCO}_{3}^{-}, \mathrm{Cl}^{-}$and $\mathrm{DOC}$ in the poplar sub-unit.

the inflow from the lake alone sustained the water table in a limited portion of the riparian zone, from P7 to R3 (Fig. 4).

\subsection{Ground water chemistry}

We found strong variations in the chemistry of subsurface water within the two sub-units sampling regions (poplar and reeds) of the lake Candia riparian zone (Table 1 and 2).

Box plots of Fig. 5 summarize the concentrations of some variables of interest measured in the poplar sub-unit as a function of the distance from the crop field. A drastic $\mathrm{NO}_{3}^{-}-\mathrm{N}$ depletion, from $14.7 \mathrm{mg} \mathrm{l}^{-1}$ to $0.08 \mathrm{mgl}^{-1}$, is evident from the upslope to the boundary between poplars and reeds. Opposite behaviour was observed in $\mathrm{HCO}_{3}^{-}$concentrations, which gradually increased from the crop field towards the lake. Within a length of $60 \mathrm{~m}$, the median alkalinity ranged from $0.60 \mathrm{meq}^{-1}$, at $\mathrm{P} 1$, to $7 \mathrm{meq}^{-1}$, at $\mathrm{P} 8$. The $\mathrm{Cl}^{-}$concentrations exhibited a bell-shaped distribution with a mean value of $12.6 \mathrm{mg} / \mathrm{l}$ at site $\mathrm{P} 1$, increasing values to a median of $17.8 \mathrm{mg} / \mathrm{l}$ at $\mathrm{P} 4$, and decreasing values to 13.7 and $8.5 \mathrm{mg} \mathrm{l}^{-1}$ at P9s and P9d, respectively. DOC levels moderately increased from a median of $2.1 \mathrm{mg} \mathrm{l}^{-1}$, upslope, to $5.3 \mathrm{mg} \mathrm{l}^{-1}$ down slope. Slight $\mathrm{NH}_{4}^{+}-\mathrm{N}$ and $\mathrm{ON}$ concentrations (0.018-0.027 $\mathrm{mg}^{-1}$ and $0.3-0.5 \mathrm{mg} \mathrm{l}^{-1}$, respectively) were measured within the poplars.

Within the reed swamp the chemistry of subsurface waters also varied strongly mainly with the depth of soils or sediments (Fig. 6). In particular, $\mathrm{HCO}_{3}^{-}$values increased linearly at a depth of $(\mathrm{R} 0.897, \mathrm{p}<0.00001)$ by a factor of 5 (from about 2 to $10 \mathrm{meq}^{-1}$ ) between 50 and $220 \mathrm{~cm}$ depth. Conversely, $\mathrm{Cl}^{-} \mathrm{SO}_{4}^{2-}$ and $\mathrm{NH}_{4}^{+}-\mathrm{N}$ linearly diminished with depth $(\mathrm{R}-0.933, \mathrm{R}-0.625, \mathrm{R}-0.556$, respectively, $\mathrm{p}<0,00001)$. Compared to the poplar sub-unit, the reed subsurface water was really poor in $\mathrm{NO}_{3}^{-}-\mathrm{N}$, with concentrations often being undetectable $\left(<0.02 \mathrm{mg} \mathrm{l}^{-1}\right)$, and relatively rich in $\mathrm{NH}_{4}^{+}-\mathrm{N}$ ranging between $0.010-0.532 \mathrm{mg} \mathrm{l}^{-1}$. Likewise ammonia, ON and DOC were shown in higher concentrations in the reeds than in the poplar sub-unit. In particular at R1s (at lower depth), close to the boundary between poplars and reeds, the median concentrations of ON and DOC reached $2.47 \mathrm{mg} \mathrm{l}^{-1}$ and $15 \mathrm{mg} \mathrm{l}^{-1}$, respectively.

The $\mathrm{O}_{2}$ measures, indicated low levels at both sub-unit sampling regions (Fig. 7), with median values ranging between $0.5-3.3 \mathrm{mg} \mathrm{l}^{-1}$. Maximum values (around $10 \mathrm{mg} \mathrm{l}^{-1}$ ) were measured at upslope (P1 and P3) while the minimum values (about $0.5 \mathrm{mg} \mathrm{l}^{-1}$ ) were measured in the reed swamp at the lower depth.

\section{Discussion}

\subsection{Denitrification indicators}

The results obtained from our study in the Candia Lake basin show that narrow regions of terrestrial-aquatic interfaces are biogeochemically highly variable environments.

The spatial trend of $\mathrm{NO}_{3}^{-}-\mathrm{N}$ concentrations observed at the poplar sub-unit, suggests that a portion of riparian region functioned largely as a nitrate sink. The $\mathrm{NO}_{3}^{-}-\mathrm{N}$ gradient was very steep, and could range from more than $6 \mathrm{mg}^{-1}$ to the detection limit over distances of less than $5 \mathrm{~m}$. 

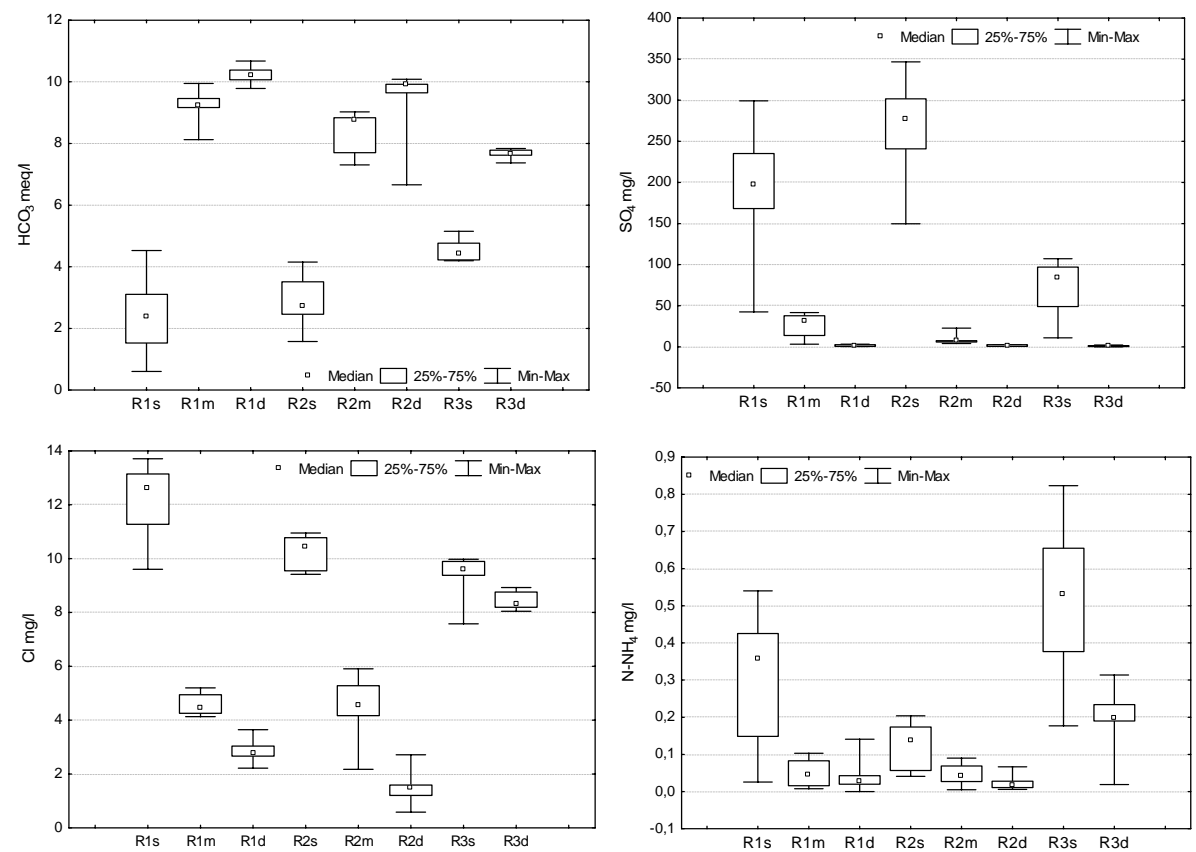

Fig. 6. Boxplot showing the distribution of $\mathrm{HCO}_{3}^{-}, \mathrm{SO}_{4}^{2-}, \mathrm{Cl}^{-}$and $\mathrm{NH}_{4}^{+}-\mathrm{N}$ in the reed sub-unit.

Both biological and physical processes can produce the $\mathrm{NO}_{3}^{-}-\mathrm{N}$ depletion observed in our study area. Changes in $\mathrm{NO}_{3}^{-}$to $\mathrm{Cl}^{-}$molar ratios are often used to infer the removal of nitrate by biological processes as chloride is a conservative ion. Large declines in chloride concentrations along a hydrologic flow path can indicate the dilution of a particular water source (e.g. agricultural runoff) by a second water source such as deep groundwater or rainfall. Such a pattern can indicate that associated declines in nitrate levels are due to the mixing of different water sources rather than actual biological removal. However, in the current paper median chloride concentrations are relatively constant in the upper transect $\mathrm{P} 1-\mathrm{P} 3$ as are median nitrate values. In contrast, in the central portion $\mathrm{P} 4-\mathrm{P} 7$ median nitrate concentrations decline rapidly whereas, chloride concentrations show small increases. These patterns do not indicate dilution, but instead suggest nitrate removal is occurring.

The patterns observed for some chemical species suggests that denitrification plays a predominant role in the observed $\mathrm{NO}_{3}^{-}-\mathrm{N}$ attenuation. Firstly, the low $\mathrm{O}_{2}$ levels in the subsurface water indicate conditions generally suitable for denitrifying bacteria (facultative anaerobes) which, in small zones where the $\mathrm{O}_{2}$ is completely removed, could shift to an anaerobic metabolism. Hypoxic conditions $\left(\mathrm{O}_{2}<2 \mathrm{mg} \mathrm{l}^{-1}\right)$ were often observed at the locations where a $\mathrm{NO}_{3}^{-}-\mathrm{N}$ consumption was evident. Some studies examining the relationship between $\mathrm{O}_{2}$ and denitrification rate, in laboratory experiments, reported a sharp inhibition effect of $\mathrm{O}_{2}$ on the microbial process at restricted range of concentration with average of $10 \mu \mathrm{mol} / 1 \mathrm{O}_{2}$ or less (Tiedje, 1988). Other Au- thors (Robertson and Kuenen, 1984) isolated an organism (Thiosphaera pantotropha) that uses both $\mathrm{O}_{2}$ and $\mathrm{NO}_{3}^{-}$as terminal electron acceptor at concentration of $90 \%$ of air saturation corresponding to a concentration of $6.9 \mathrm{mg} / \mathrm{l}$. Most likely the $\mathrm{O}_{2}$ threshold that may cause the cessation of denitrification varies among organisms. Recent "in field" studies indicate that denitrification can occur even with detectable $\mathrm{O}_{2}$ concentrations. This may be explainable considering that this bacterial process occur in microsites, often defined "hot spots", where $\mathrm{O}_{2}$ has been completely removed (Mariotti, 1986; Parkin, 1987). For example, hot spots of denitrification may occur along root channels where moisture and organic matter content are high (McClain et al., 2003), or in small patches of organic matter in the $\mathrm{C}$ horizon of riparian soils (Jacinthe et al., 1998). Hill et al. (2000) also reported the occurrence of denitrification at depth, at the interfaces between sands and peat or buried channel deposits in a southern Ontario riparian zone. Many studies on riparian areas reported a sharp decline of $\mathrm{NO}_{3}^{-}$in groundwater at $\mathrm{O} 2$ concentration of $<2-3 \mathrm{mg} / \mathrm{L}$ (Cey et al., 1999; Vidon and Hill, 2004) and this can be interpreted as a condition for denitrification to occur.

We found a significant inverse linear relationship between $\mathrm{NO}_{3}^{-}-\mathrm{N}$ and $\mathrm{HCO}_{3}^{-}$concentrations $(\mathrm{R} 0.845 \mathrm{p}<0.0001$ ) (Fig. 8) that indirectly indicates the occurrence of denitrification. In fact this microbial reduction implies an alkalinity increase of 1 eq per mole of nitrate reduced (Stumm and Morgan, 1981). The relationship between $\mathrm{HCO}_{3}^{-}$and $\mathrm{NO}_{3}^{-}$ is not generally analysed in experimental surveys aimed at studying $\mathrm{N}$ dynamic in riparian areas. A link between the loss of $\mathrm{O}_{2}$ and $\mathrm{NO}_{3}^{-}$and the production of large amounts of 

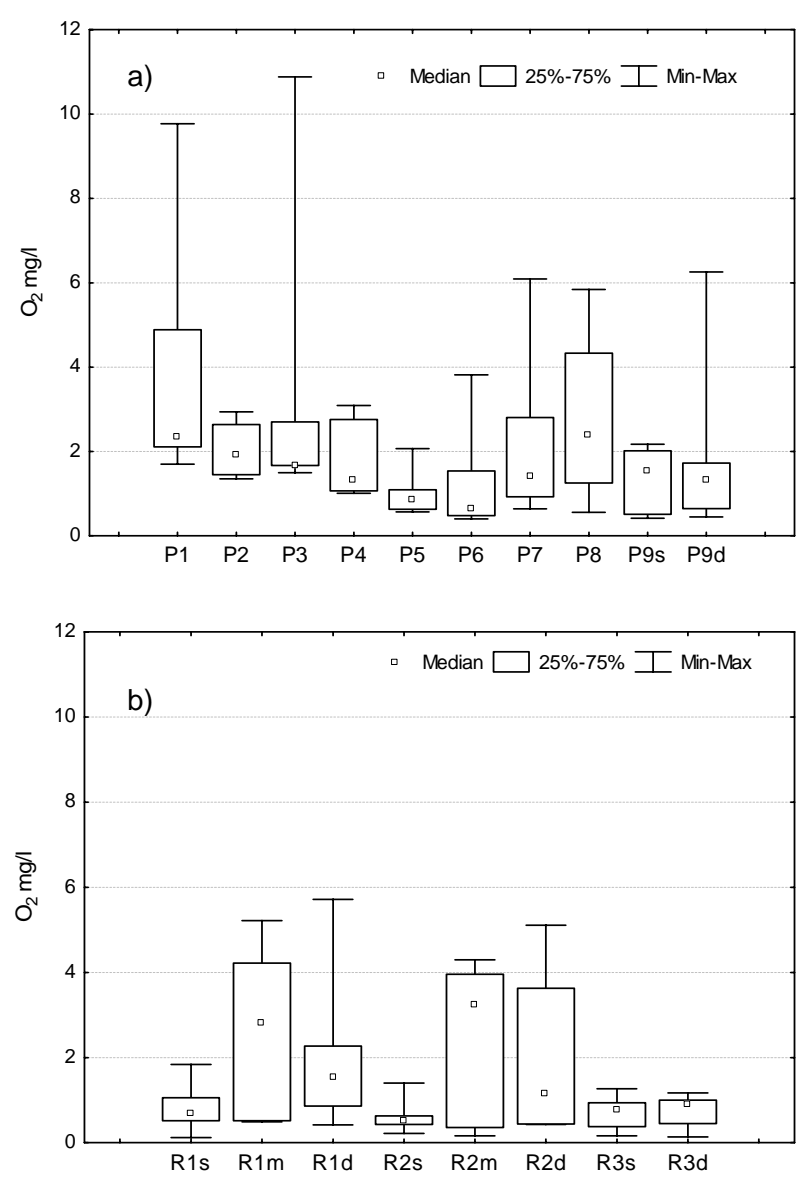

Fig. 7. Boxplot showing the distribution of $\mathrm{O}_{2}$ in the poplar (a) and in the reed sub-unit (b).

$\mathrm{HCO}_{3}^{-}$is reported for a glacial outwash aquifer in Minnesota by Puckett and Cowdery (2002). In a study we carried out in a river wetland (Balestrini et al., 2004 and 2007) the declining nitrate found in groundwater along a transect, from a crop field to the stream, was not related to alkalinity. The alkalinity seems to be a sensitive indicator of the extent of denitrification but only in specific types of wetlands. Our data set and literature are not broad enough to identify the environmental features, presumably geological and hydrological, which favour $\mathrm{HCO}_{3}^{-}$accumulation in groundwater as a consequence of redox reactions.

An additional sign of denitrification activity was the presence of detectable $\mathrm{NO}_{2}^{-}-\mathrm{N}$ concentrations at the P2-P7 piezometers of the poplar sub-unit (Table 1). The dynamic of $\mathrm{NO}_{2}^{-}$in soil and water can be very rapid as it can be produced or consumed by a number of biological or chemical reactions. Some studies report that nitrification and denitrification are the main processes contributing to $\mathrm{NO}_{2}^{-}$accumulation in soil (Burns et al., 1996). In our study area $\mathrm{NH}_{4}^{+}-\mathrm{N}$ concentration in groundwater was very low and, conversely, there was a great input of $\mathrm{NO}_{3}^{-}-\mathrm{N}$, consequently we can expect that denitrification was the major $\mathrm{NO}_{2}^{-}$source process.

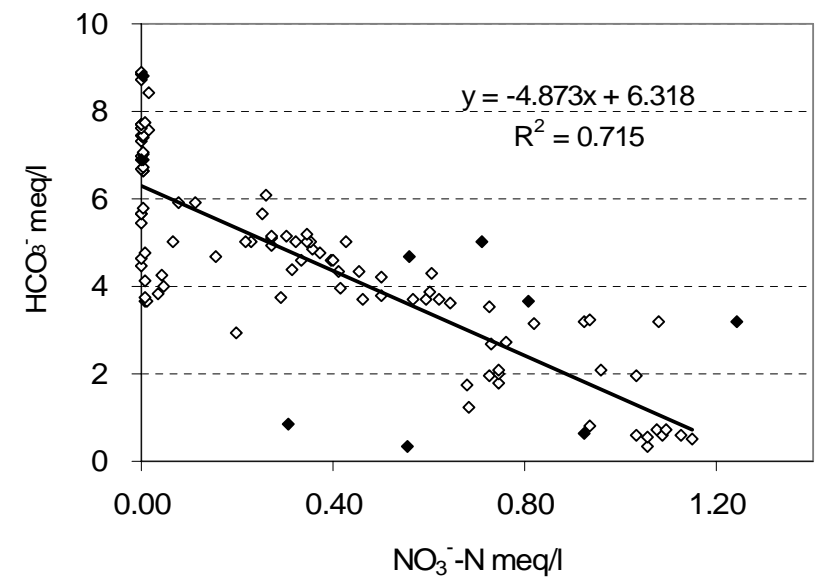

Fig. 8. Linear regression between $\mathrm{NO}_{3}^{-}-\mathrm{N}$ and $\mathrm{HCO}_{3}^{-}$concentration in poplar sub-unit groundwater samples. Solid dots represent an intense rainy event (December 2003) not included in the regression.

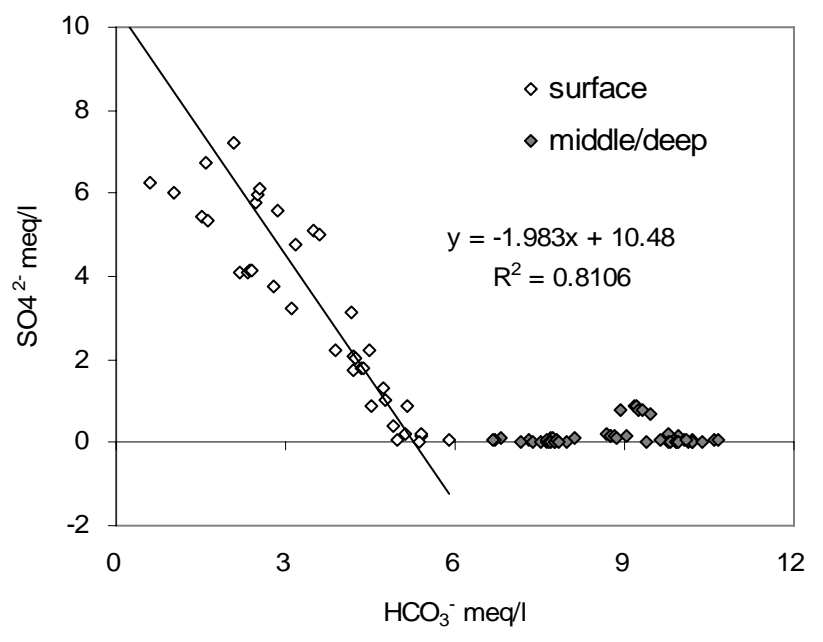

Fig. 9. Relationship between $\mathrm{SO}_{4}^{2-}$ vs. $\mathrm{HCO}_{3}^{-}$concentration from groundwater samples collected at reed sub-unit. The equation and the coefficient of determination refers to the linear regression found for the surface samples.

Within the reed swamp, the very low input of $\mathrm{NO}_{3}^{-}-\mathrm{N}$ from both the adjacent terrestrial zone and the water of the lake, probably severely constrained the denitrification. In this system, which was very poor in oxygen, $\mathrm{SO}_{4}^{2-}$ could become a suitable electron acceptor for the oxidation of the organic $\mathrm{C}$. As sulphate reduction also produces alkalinity (Stumm and Morgan, 1981) the high significant inverse relation found between $\mathrm{SO}_{4}^{2-}$ and $\mathrm{HCO}_{3}^{-}$(R 0.901, p $<0.00001$; Fig. 9) supported our hypothesis. In addition, the release of sulphide was frequently detected during the sampling, by the typical smell of rotten eggs. The pattern described follows the wellstudied thermodynamic sequence reported for lake or marine sediments (Stumm and Morgan, 1981; Kuivila and Murray, 

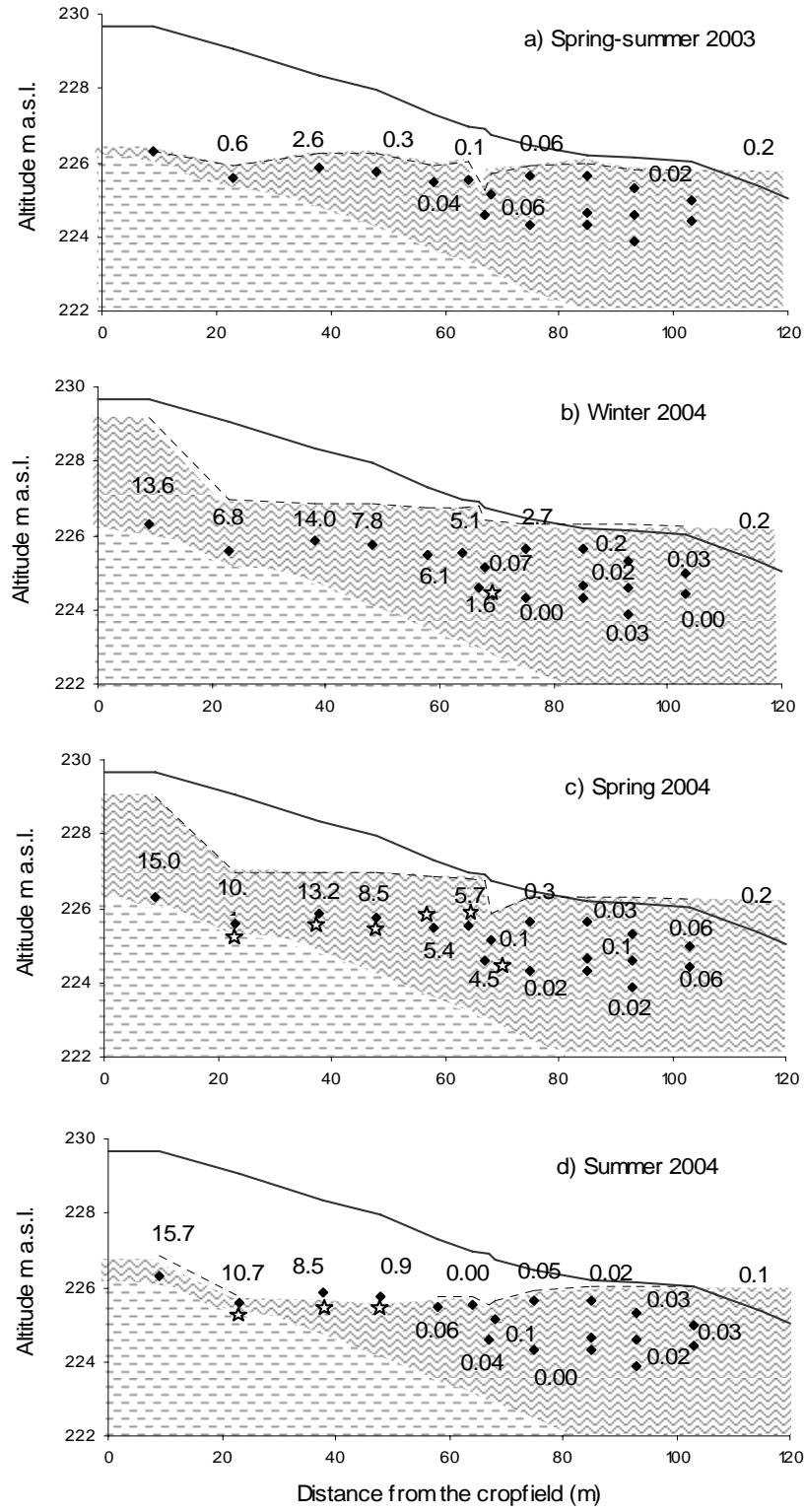

\& $0.1-0.4 \mathrm{mg} \mathrm{N}-\mathrm{NO}_{2} \mathrm{I}^{-1}$

ground water

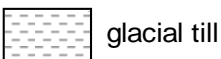

Fig. 10. Mean nitrate and nitrite (ఓ⿱宀) ) concentrations ( $\mathrm{mg} \mathrm{N}^{-1}$ ) along the studied transect during: (a) March-September 2003, (b) December-March 2004, (c) April-May 2004 and (d) June-July 2004.

1984, Dillon et al., 1997), but is not often used to interpret the chemical transformation in riparian zones (Hedin et al., 1998; Pukett and Cowdery, 2002; Hill et al., 2000). As shown in Fig. 8 at the higher depth $(150-220 \mathrm{~cm})$ where all the sulphate was consumed, the alkalinity continued to increase, from about 6 to 11 meq $\mathrm{l}^{-1}$ and the chloride gradually decreased. Both these findings are difficult to explain. In
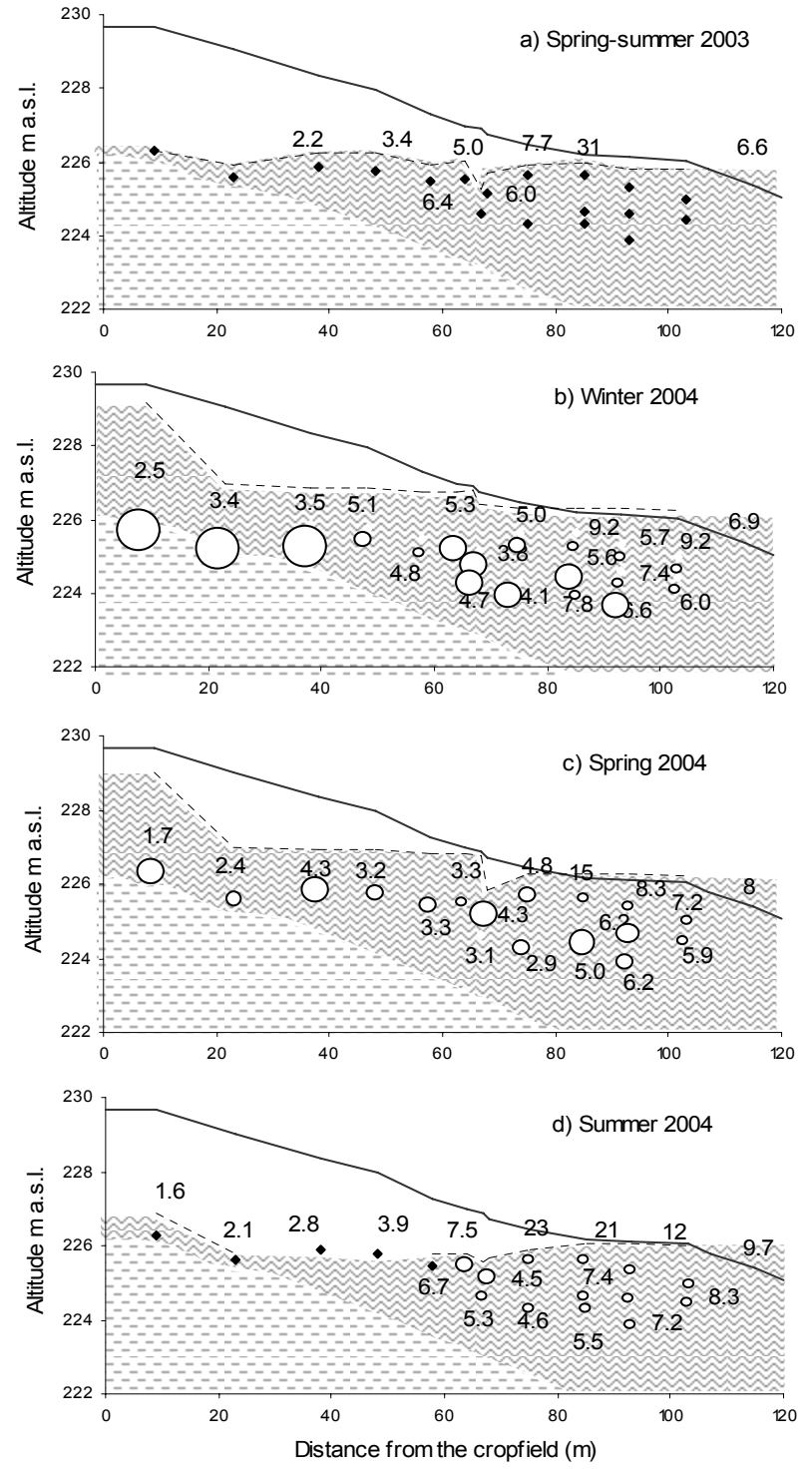

$$
\begin{array}{ll}
\bigcirc \geq 10 \mathrm{mg} \mathrm{O}_{2} \mathrm{I}^{-1} & 0<1 \leq 2 \mathrm{mg} \mathrm{O}_{2} \mathrm{I}^{-1} \\
\bigcirc>2<6 \mathrm{mg} \mathrm{O}_{2} \mathrm{I}^{-1} & \circ \leq 1 \mathrm{mg} \mathrm{O}_{2} \mathrm{I}^{-1}
\end{array}
$$

ground water

glacial till

Fig. 11. Mean DOC concentrations $\left(\mathrm{mg} \mathrm{l}^{-1}\right)$ along the studied transect and dissolved oxygen ranges during: (a) March-August 2003, (b) December-March 2004, (c) April-May 2004 and (d) June-July 2004.

fact the occurrence of methanogenesis, expected on thermodynamic basis, does not affect alkalinity. On the other hand we have to exclude the effect of dilution processes caused by the inflow of lake water (see Tables 1 and 2). We could hypothesise the presence of older waters at depth, isolated by surface waters, characterised by lower $\mathrm{Cl}^{-}$and $\mathrm{SO}_{4}^{2-}$ and higher $\mathrm{HCO}_{3}^{-}$concentrations. 
In the reed swamp, characterized by still water and abundant plant biomass, the main source of mineralized nitrogen was represented by ammonia, but the major nitrogen species is organic nitrogen with relatively high concentrations, ranging from 0.35 to $4.3 \mathrm{mg} \mathrm{l}^{-1}$. The restricted amount of nitrate reaching the reed stand drives to suppose that other processes instead of Dissimilative Nitrate Reduction to Ammonium could have a crucial role in the $\mathrm{N}$ dynamic in this unit. On the other hand the great availability of organic matter deriving from plant decomposition suggest the importance of ammonification. The possibility that the Phragmites belt could act as a source of $\mathrm{NH}_{4}$ and $\mathrm{ON}$ for the lake has to be evaluated with more specific investigations.

\subsection{Environmental factors affecting nitrogen dynamics}

The results gained from the hydrochemical monitoring over 18 months allowed us to trace the sequence of processes that occurred in the lake Candia wetland over the course of a year and to identify the main environmental variables affecting nitrogen cycling. The sequence of hydrological and biochemical changes are presented in Figs. 10 and 11 as a series of schematic snapshots.

The long period of drought during spring-summer 2003 caused the progressive lowering of the water table in all the transect resulting in the complete disconnection between the poplar and reed sub-units in September. In these conditions the spring fertilizer applications did not generate the expected rise of $\mathrm{NO}_{3}^{-}$in the groundwater and the observed levels remained very low during all of 2003 (Fig. 10a).

The abundant precipitation which occurred in December 2003 promoted the prompt development of the shallow aquifer and the consequent hydrological connection of all the piezometers (Fig. 10b). The interaction of the rising water table with the $\mathrm{NO}_{3}^{-}$rich soil waters of the crop field, caused a sharp increase of $\mathrm{NO}_{3}^{-}$concentrations, simultaneously from P1 to P6 sites. At P7 (67 m from the crop field) and $\mathrm{P} 9 \mathrm{~s}$ (75 $\mathrm{m}$ from the crop field, at $80 \mathrm{~cm}$ depth) the $\mathrm{NO}_{3}^{-}$ flush was detected a month later, during the January sampling. Conversely, the $\mathrm{NO}_{3}^{-}$concentration did not rise at the deeper piezometers, P8 and P9d (157 and $216 \mathrm{~cm}$ depth, respectively) and in the whole reed sub-unit. The elevated $\mathrm{O}_{2}$ concentrations measured during the February sampling (Fig. 11b), with levels over $10 \mathrm{mg} / 1$ from P1 to P3, indicated the input of water rich in electron donors. In the rest of the transect the $\mathrm{NO}_{3}^{-}$concentrations gradually decreased along with the oxygen values.

During spring (Fig. 10c), the water table remained quite high and the $\mathrm{NO}_{3}^{-}$continued to flush from the upland (P1), where the levels were steady around $14-15 \mathrm{mg} \mathrm{N}^{-1}$, thereby ensuring the supply of $\mathrm{NO}_{3}^{-}$for denitrification in the riparian zone. The $\mathrm{NO}_{3}^{-}$pattern did not differ significantly from previous months but conditions appeared more suitable for denitrification. In fact the $\mathrm{O}_{2}$ concentrations were remarkably lower compared to the winter period with most of the loca-

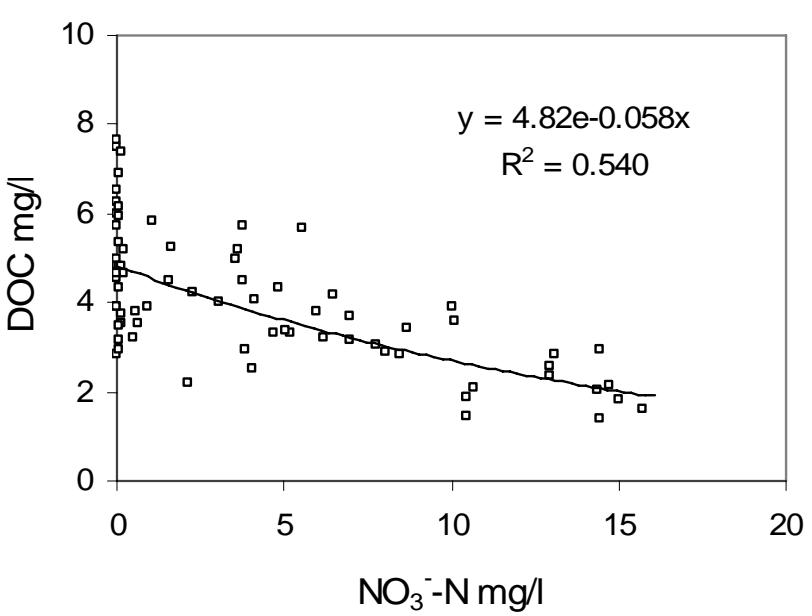

Fig. 12. Relationship of $\mathrm{NO}_{3}^{-}-\mathrm{N}$ vs. DOC concentrations from ground water samples at the poplar sub-unit.

tions characterized by values less than $2 \mathrm{mg} \mathrm{l}^{-1}$ (Fig. 11c). In addition, we detected the presence of nitrite, an intermediate product of the denitrification reaction, in locations characterized by low oxygen, and an elevated availability of nitrate (Figs. 10-11c).

Later on, over the dry and hot summer season (Fig. 10d), the water table level declined at all locations up to P7, as well as the nitrate concentrations. A marked and abrupt decline of $\mathrm{NO}_{3}^{-}-\mathrm{N}$ was evident between $\mathrm{P} 3$ and $\mathrm{P} 4$ where the concentration decreased from 8.5 to $0.9 \mathrm{mg} \mathrm{l}^{-1}$ within $10 \mathrm{~m}$. Thus, the nearly complete nitrate removal $\left(\mathrm{NO}_{3}^{-}-\mathrm{N}<0.1 \mathrm{mgl}^{-1}\right)$ occurred in a larger area covering $60 \%$ of the whole wetland, despite the constant input of nitrate from the P1 site. The $\mathrm{O}_{2}$ levels further diminished and, conversely, the DOC availability increased mainly in the transition area between poplar and reeds (Fig. 11d). At the end of July when the complete drying out of the shallow aquifer caused a disconnection between upland and the locations closer to the reed swamp (P7-P9), the $\mathrm{NO}_{3}^{-}$source area stopped supplying the riparian zone.

The seasonal evolution of $\mathrm{NO}_{3}^{-}-\mathrm{N}$ in the subsurface waters of the poplar sub-unit suggests the importance of temperature in the biological processes responsible for $\mathrm{N}$ removal. The increase in temperature of $5-7^{\circ} \mathrm{C}$ observed in the ground water from February to the end of May could have stimulated the denitrification. Some studies have reported a significant direct effect of temperature on denitrification rates (Martin et al., 2000; Knowles, 1982). The renewal of the vegetation activity in the spring and summer months may also be an important factor in the decreasing nitrate losses from the soil at that time of the year. Higher daily soil respiration rates and an abundant biomass of live roots in spring and early summer were reported for a poplar stand in a riparian area in Central Iowa (Tufekcioglu et al., 1999). The rapid increase of DOC concentration observed from May to June at certain 
sites (P5-P9) may derive from greater organic matter inputs from plants to the soil, therefore providing better conditions for nutrient sequestration within the riparian area. Some studies suggest that denitrification can be limited by a supply of organic carbon (Hedin et al., 1998; Starr and Gillham, 1993; Bradley et al., 1992; Hill et al., 2000) as it provides energy to the bacterial community and, indirectly, promotes the occurrence of anoxic conditions through $\mathrm{O}_{2}$ consumption by heterotrophic bacteria. Hedin et al. (1998) reported that $\mathrm{NO}_{3}$ only accumulated in subsurface waters with DOC concentrations of less than $2 \mathrm{mg}^{-1}$ in Smith Creeck nearstream environments; while other Authors (Starr and Gillham, 1993) suggest that concentrations of $4-5 \mathrm{mg} \mathrm{l}^{-1}$ are not enough to sustain denitrification. The relationship found between DOC and $\mathrm{NO}_{3}^{-}-\mathrm{N}$ using the data relative to $\mathrm{P} 1-\mathrm{P} 9$ sites (Fig. 12), is similar to that reported by Devito et al. (2000) for a sand aquifer in Ontario (Canada) and suggests that denitrification can be limited by a carbon supply of less than $3 \mathrm{mg} \mathrm{l}^{-1}$. DOC concentrations always higher than $3 \mathrm{mg}^{-1}$ have been measured, within the poplar sub-unit, starting from P5 to P9 (Fig. 11). The presence of black soil layers rich in organic carbon deposits were also detected at a greater depth (to $150-170 \mathrm{~cm}$ ) at the same sites. On the contrary, at $\mathrm{P} 1$ where the $\mathrm{NO}_{3}^{-}$level did not decline even in summer, the DOC concentration never exceeded $3 \mathrm{mg} \mathrm{l}^{-1}$.

In addition to its role as an organic $\mathrm{C}$ supplier, the direct role of vegetation in increasing the $\mathrm{N}$ uptake rate during the growing season has to be expected. In this regard, it is important to note that the temperature increase, typical of the summer months, coincided with soil drying and a lowering of the water table. Some studies have demonstrated that the nutrient plant uptake is controlled by the water table fluctuations, as plant root biomass has been shown to sharply decline with depth (Ehrenfeld et al., 1992; Tufekcioglu et al., 1999). Within the poplar sub-unit, the water table lowered by about $70 \mathrm{~cm}$ reaching a depth of $1-3 \mathrm{~m}$ during the summer. We did not investigate the distribution of the roots in the soil profile but a number of papers indicate that poplars are generally characterized by a very deep root system. Tufekcioglu et al. (1999) detected the presence of coarse roots of at least $180 \mathrm{~cm}$ under poplars in a fine-loamy riparian soil; Heilman et al. (1994) reported that roots of 4-year-old hybrids of Populus trichocarpa $x$ Populus deltoides extended to depths beyond $3.2 \mathrm{~m}$ and Gifford (1966) reported a similar rooting depth, about $290 \mathrm{~cm}$, for Populus tremuloides in a sandy loam soil. On the base of these findings it is reasonable to hypothesize that poplar trees play a role in lowering the subsurface nitrate concentrations during the growing season at Candia Lake wetland.

The results obtained indicate that the efficiency of the wetland study in buffering the flux of $\mathrm{N}$ is also associated with the topographic features of the area, in that significant $\mathrm{NO}_{3}^{-}$$\mathrm{N}$ removal occurred in a specific portion of the transect characterized by the diminishing slope. In this area (from P5 to
R3) the fluctuations of the water table were more restricted and during several events the ground water reached and rose above the soil surface. Recent research carried out in different riparian areas spread all over Europe demonstrated that the functioning of riparian areas depends on the existence of topographic and soil conditions that produce, at least seasonally, a high water table (Burt et al., 2002). The saturation of the upper soil layers rich in organic $\mathrm{C}$ creates a suitable condition for denitrification (Burt et al., 1999; Cosandey et al., 2003) and consequently enhances the $\mathrm{N}$ buffer effect of riparian zones. The development of soil saturation also depends on the hydraulic conductivity of the soil which is important in optimizing the ground water residence time (Burt et al., 1999 and 2002). The aquifer has to be permeable enough to support interactions with the biotic components or allow for the development of anoxic conditions. On the other hand low hydraulic conductivity may give origin to a subsurface flux of $\mathrm{NO}_{3}^{-}-\mathrm{N}$ that is too small to be effective. In the upper part of the study area the presence of conductive soil layers $\left(138-328 \mathrm{~cm} \mathrm{~d}^{-1}\right)$ in depth permitted the transport of water rich in $\mathrm{NO}_{3}^{-}$. The diminishing of the hydraulic conductivity to values ranging from 67 to $2 \mathrm{~cm} \mathrm{~d}^{-1}$, respectively from P5 to $\mathrm{P} 8$ most likely promoted the bacterial processes.

\section{Conclusions}

Our study of Lake Candia clearly demonstrates the crucial role of wetlands in the abatement of $\mathrm{N}$ flux from agricultural sources to aquatic ecosystems. The metabolic activity of bacterial communities, based on the differential use of electron donors and acceptors in redox reactions to derive energy for growth, is the key function of this system. In a thermodynamic perspective we can identify three different functional units within the study area: 1) the steep upslope zone adjacent to the crop field where $\mathrm{NO}_{3}^{-}-\mathrm{N}$ rich and oxic groundwater supported the aerobic respiration, 2) a flatter zone adjacent to the reed swamp dominated by denitrification that consumed all $\left.\mathrm{NO}_{3}^{-}, 3\right)$ the reed swamp rich in electron donors, especially DOC, and poor in both oxygen and nitrate; the redox condition favoured bacteria capable of deriving energy from sulphate. The biochemical responses occurring in these different units are coupled to the hydrological responses and the different reaction to rainfall inputs over the year. The topography assumes a critical role in regulating the strength of the hydrological connections within the riparian area.

This successful experimental approach, which comprises both biogeochemical and hydrological monitoring, allows us to gain knowledge of the role played by physical and biological processes in controlling the $\mathrm{N}$ dynamic within this specific portion of the Candia Lake catchment. Although the results presented here are obtained from a single case study in a specific climatic environment, they may contribute to developing models on $\mathrm{N}$ cycling processes in catchments where $\mathrm{N}$ 
export can be predicted and also establish the extent to which riparian zones function as buffer systems.

The mechanistic explanations on denitrification through the analysis of the relationship between alkalinity and nitrate concentrations at soil-lake interfaces represents an innovative approach. In the wetland studied, the alkalinity was shown to be a valuable indicator of the change in redox conditions Further researches will be aimed at analyzing the relationship between $\mathrm{HCO}_{3}^{-}$and $\mathrm{N}_{2} \mathrm{O}$, in controlled experiments using acetylene to block the final step of denitrification.

Acknowledgements. Our thanks go to A. De Paolis for his help with field activities and F. Salerno for his support with hydrology and the drawing of maps. We would also like to thank the Institute of Ecosystem Study CNR (Verbania Pallanza, Italy) for providing precipitation data. Funding was provided by the national project MICARI - Miglioramento della capacità dei corpi idrici superficiali (D.M. 408 Ric. 20.03.2002).

Edited by: A. Ghadouani

\section{References}

Autorità di Bacino del fiume Po: Progetto di Piano di stralcio per il controllo dell'Eutrofizzazione, Autorità di Bacino del fiume Po, Parma, 12 pp., 2003.

Balestrini, R., Arese, C., and Delconte, C.: Funzionalita' degli ecosistemi acquatici: il ruolo delle fasce riparie nella dinamica dei nutrienti, Quaderno Ist. Ric. Acque, 121, 127 pp., Rome (Italy), IRSA, 2004.

Balestrini, R., Arese, C., and Delconte, C.: Nitrogen removal in a freshwater riparian wetland: an example from Italian lowland spring, Verh. Int. Verein. Limn., 29/5, 2217-2220, 2007.

Blicher-Mathiesen, G. and Hoffman, C. C.: Denitrification as a sink for dissolved nitrous oxide in a freshwater riparian fen, J. Environ. Qual., 28, 257-262, 1999.

Borin, M., Bigon, E., Zanin, G., and Fava, L.: Performance of a narrow buffer strip in abating agricultural pollutants in the shallow subsurface water flux, Environ. Pollut., 131, 313-321, 2004.

Bouwer, H. and Jackson, R. D.: A slug test for determining hydraulic conductivity of unconfined aquifers with completely or partially penetrating wells, Water Resour. Res., 12, 3, 423-428, 1976.

Bradley, P. M., Fernandez, M., and Chapelle, F. H.: Carbon limitation of denitrification rates in an anaerobic groundwater system, Environ. Sci. Technol., 26, 2377-2381, 1992.

Burns L. C., Stevens R. J., and Laughlin R. J.: Production of nitrite in soil by simultaneous nitrification and denitrification, Soil Boil. Biochem., 28, (4-5), 609-616, 1996.

Burt, T. P, Matchett, L. S, Goulding, K. W. T., Webster, C. P., and Haycock, N. E.: Denitrification in riparian buffer zones: the role of floodplain sediments, Hydrol. Process., 13, 1451-1463, 1999.

Burt, T. P., Pinay, G., Matheson, F. E., Haycock, N. E., Butturini, A., Clement, J. C., Danielescu, S., Dowrick, D. J., Hefting, M. M., Hillbricht-Ilkowska, A., and Maitre, V.: Water table fluctuations in the riparian zone: comparative results from a pan-European experiment, J. Hydrol., 265, 129-148, 2002.
Cey, E. E., Rudolph, D. L., Aravena, R., and Parkin, G.: Role of the riparian zone in controlling the distribution and fate of agricultural nitrogen near a small stream in southern Ontario, J. Contam. Hydrol., 37, 45-67, 1999.

Ciampittiello, M., De Bernardi, R., Galanti, G., Giussani, G., Cerruti, I., Salerno, F., and Tartari, G.: Sito di Candia, In Attività 0 - Definizione degli ambiti idrografici e idrogeologici dei bacini oggetto dello studio, Report finale Progetto MICARI, 122 pp. 2005.

Cosandey, A. C., Maitre, V., and Guenat, C.: Temporal denitrification patterns in different horizons of two riparian soils, Eur. J. Soil Sci., 54, 25-37, 2003.

DECRETO LEGISLATIVO N. 152.: Disposizioni sulla tutela delle acque dall'inquinamento e recepimento della direttiva 91/676/CEE relativa alla protezione delle acque dall'inquinamento provocato dai nitrati provenienti da fonti agricole. Supplemento Ordinario no 101/L alla Gazzetta Ufficiale, 29 Maggio 1999, 124, 1999.

Devito, K. J, Dillon, P. J., and Lazerte, B. D.: Phosphorus and nitrogen retention in five Precambrian shield wetlands, Biogeochemistry, 8, 185-204, 1989.

Devito, K. J., Fitzgerald, D., Hill, A. R., and Aravena, R.: $\mathrm{NO}_{3}$ dynamics in relation to lithology and hydrologic flow path in a river riparian zone, J. Environ. Qual., 29, 1075-1084, 2000.

Dillon, P. J., Evans, H. E., and Girard, R.: Hypolymnetic alkalinity generation in two dilute oligotrophic lakes in Ontario, Canada, Water, Air and Soil Poll., 99, 373-380, 1997.

Ehrenfeld, J. G., Kaldor, E., and Parmelee, R. W.: Vertical distribution of roots along a soil toposequence in the New Jersey Pinelands, Canad. J. Forest. Res., 22, 1929-1936, 1992.

EU: Directive 2000/60/EC of the European Parliament and of the Council of 23 October 2000 establishing a framework for Community action in the field of water policy, Official Journal of the European Communities L, 327, 22.12.2000, 1-72, 2000.

Fetter, C. W.: Applied Hydrogeology (4th ed), Prentice Hall, Upper Saddle River, NJ, 691 pp., 2001.

Galanti, G. and Romo, S.: Epiphyton biomass on the floating leaves water chestnut (Trapa natans) and its importance for the carbon balance in the eutrophic Lake Candia (N. Italy), Memorie Istituto Italiano Idrobiologia, 56, 95-111, 1997.

Gaudette, H. E., Flight W. R., Toner, L., and Folger, D. W.: An inexpensive titration method for the determination of organic carbon in recent sediments, J. Sediment Petrol., 44, 249-253, 1974.

Gifford, G. F.: Aspen root studies on three sites in northern Utah, American Midland Naturalist, 75, 132-141, 1966.

Groffman, P. M., Howard, G., Gold, A. J., and Nelson, W. M.: Microbial $\mathrm{NO}_{3}$ processing in shallow groundwater in a riparian forest, J. Environ. Qual., 25, 1309-1316, 1996.

Haycock, N. E. and Pinay, G.: Groundwater $\mathrm{NO}_{3}$ dynamic in grass and poplar vegetated riparian buffer strips during the winter, J. Environ. Qual., 22, 273-278, 1993.

Haycock, N. E., Pinay, G., and Walker, C.: Nitrogen retention in river corridors: European perspective, Ambio, 22, 340-346, 1993.

Hedin, L. O., von Fischer, J. C., Ostrom, N. E., Kennedy, B. P, Brown, M. G., and Robertson, G. P.: Thermodynamic constrains on nitrogen transformations and other biogeochemical processes at soil-stream interfaces, Ecology, 79, 684-703, 1998.

Heilman, P. E., Ekuan, G., and Fogle, D.: Above and belowground 
biomass and fine roots of 4-years-old hybrids of Populus trichocarpa $\mathrm{x}$ Populus deltoids and parental species in short rotation culture, Canad. J. Forest Res., 24, 1186-1192, 1994.

Hill, A. R.: Ground water flow paths in relation to nitrogen chemistry in near-stream zone, Hydrobiologia, 206, 39-52, 1990.

Hill, A. R., Devito, K. J., Campagnolo, S., and Sanmugadas, K.: Subsurface denitrification in a forest riparian zone: Interactions between hydrology and supplies of $\mathrm{NO}_{3}$ and organic carbon, Biogeochemistry, 51, 193-223, 2000.

Jacinthe, P. A., Groffman, P. M., Gold, A. J., and Mosier, A.: Patchiness in microbial nitrogen transformations in groundwater in a riparian forest, J. Environ. Qual., 27, 156-164, 1998.

Knowles, R.: Denitrification, Microbiol. Rev., 46, 43-70, 1982.

Kuivila, K. M. and Murray, J. W.: Organic matter diagenesis in freshwayer sediments: The alkalinity and total $\mathrm{CO}_{2}$ balance and methane production in the sediments of Lake Washington, Limnol. Oceanogr., 29, 1218-1230, 1984.

Mariotti, A.: Denitrification in groundwaters, principles and methods for its identification: a review, J. Hydrol., 88, 1-23, 1986.

Martin, L. A., Mulholland, P. J., Webster, J. R., and Valett, H. M.: Denitrification in sediments of headwaters streams in the southern Appalachian Mountains, USA, J. N. Am. Benthol. Soc., 20, 505-519, 2001.

McClain, M. E., Boyer E. W., Dent, C. L., Gergel, S. E., Grimm, N. B., Groffman, P. M., Hart, S. C., Harvey, J. W., Johnston, C. A., Mayorga, E., McDowell, W. H., Pinay, G.: Biogeochemical Hot Spots and Hot Moments at the Interface of Terrestrial and Aquatic Ecosystems, Ecosystems, 6, 301-312, 2003.

Mitsch, W. J. and Gosselink, J. G.: Wetlands, Third Edition, John Wiley \& Sons, Canada, 920 pp., 2000.

Mosello, R., Derome, J., Derome, K., Ulrich, E., Dahlin, T., and Marchetto, A., Tartari, G.: Atmospheric deposition and soil solution Working Ring Test 2002, EC Technical Report, Fontainebleu, France, 69 pp., 2002.

O'Neill, G. J. and Gordon A. M.: The nitrogen filtering capability of Carolina poplar in an artificial riparian zone, J. Environ. Qual., 23, 1218-1223, 1994.
Parkin, T. B.: Soil microsites as a source of denitrification variability, Soil Sci. Soc. Am. J., 51, 1194-1199, 1987.

Peterjohn, W. T. and Correll, D. L.: Nutrient dynamics in an agricultural watershed: observations on the role of riparian forests, Ecology, 65, 1466-1475, 1984.

Pinay, G., Black, V. J., Planty-Tabacchi, A. M., Gumiero, B., and Décamps, H.: Geomorphic control of denitrification in large river floodplain soils, Biogeochemistry, 50, 163-182, 2000.

Puckett, L. J. and Cowdery, T. K.: Transport and fate of $\mathrm{NO}_{3}$ in a glacial outwash aquifer in relation to ground-water age, land use practices and redox processes, J. Environ. Qual., 31, 782-796, 2002.

Sabater, S., Butturini, A., Clement, J. C., Burt, T., Dowrick, D., Hefting, M., Maître, V., Pinay, G., Postolache, C., Rzepecki, M., and Sabater, F.: Nitrogen removal by riparian buffers along a European climatic gradient: patterns and factors of variation, Ecosystems, 6, 20-30, 2003.

Starr, R. and Gillham, R. W.: Denitrification and organic carbon availability in two aquifers, Ground Water, 31, 934-947, 1993.

Stumm, W. and Morgan, J. J.: Aquatic chemistry: an introduction emphasizing chemical equilibria in natural waters, John Wiley \& Sons, New York, USA, 780 pp. 1981.

Tiedje, J. M.: Ecology of denitrification and dissimilatory nitrate reduction to ammonium, in: Biology of Anaerobic Microrganisms, edited by: Zehnder, A. J. B., 179-244, John Wiley \& Sons, New York, 1988.

Tufekcioglu, A., Raich, J. W., Isenhart, T. M., and Schultz, R. C.: Fine root dynamics, coarse root biomass, root distribution, and soil respiration in a multispecies riparian buffer in Central Iowa, USA, Agroforest. Syst., 44, 163-174, 1999.

Vidon, P. and Hill, R. A.: Denitrification and patterns of electron donors and acceptors in eight riparian zones with contrasting hydrogeology, Biogeochemistry, 71, 259-283, 2004.

Wetlands Horizontal Guidance: Draft Horizontal Guidance Document on the Role of Wetlands in the Water Framework Directive, Common Implementation Strategy for the Water Framework Directive (2000/60/EC), 65 pp., 2003. 